\title{
Correction to: Psychometric properties of the Activities Scale for Kids-performance after allogeneic hematopoietic stem cell transplantation in adolescents and children
}

\section{Results of a prospective study on behalf of the German-Austrian-Swiss GVHD consortium}

\begin{abstract}
Anita Lawitschka - Matthias Brunmair - Dorothea Bauer - Natalia Zubarovskaya - Rosemarie Felder-Puig • Brigitte Strahm · Peter Bader · Gabriele Strauss · Michael Albert · Irene von Luettichau · Hildegard Greinix • Daniel Wolff · Christina Peters
\end{abstract}

Published online: 1 July 2021

(C) The Author(s) 2021

\section{Correction to: \\ Wien Klin Wochenschr 2020 \\ https://doi.org/10.1007/s00508-020-01641-w}

The original version of this article unfortunately contained a mistake. Due to a breach of copyright, Fig. 1 "ASK@-Performance SCORE SHEET. The ASKp domains, items and response option" had to be removed from the article. The authors apologize for the mistake. The original article has been corrected.

The online version of the original article can be found under https://doi.org/10.1007/s00508-020-01641-w.

A. Lawitschka, MD $(\varangle) \cdot$ D. Bauer $\cdot$ N. Zubarovskaya

C. Peters

St. Anna Children's Hospital, SCT-Outpatient \& Aftercare Clinic, Medical University Vienna and Children's Cancer Research Institute, Kinderspitalgasse 15, 1090 Vienna, Austria

anita.lawitschka@stanna.at

\section{Brunmair}

Department of Psychology, University of Wuerzburg,

Wuerzburg, Germany

R. Felder-Puig

Ludwig Boltzmann Institute Health Technology Assessment, Vienna, Austria

\section{B. Strahm}

Department of Paediatrics and Adolescent Medicine,

Division of Paediatric Haematology and Oncology, Medical

Centre, University of Freiburg, Freiburg, Germany

P. Bader

Division for Stem Cell Transplantation, University Children's

Hospital, Frankfurt/Main, Germany
Funding Open access funding provided by Medical University of Vienna.

Open Access This article is licensed under a Creative Commons Attribution 4.0 International License, which permits use, sharing, adaptation, distribution and reproduction in any medium or format, as long as you give appropriate credit to the original author(s) and the source, provide a link to the Creative Commons licence, and indicate if changes were made. The images or other third party material in this article are included in the article's Creative Commons licence, unless

\section{G. Strauss}

Department for Paediatric Oncology and Haematology, HELIOS Klinikum Berlin-Buch, Berlin, Germany

\section{Albert}

Department of Pediatrics, Division of Pediatric Haematology and Oncology, Dr von Hauner Children's Hospital, LMU, Munich, Germany

I. von Luettichau

Children's Hospital Medical Centre, Technical University of Munich, Munich, Germany

H. Greinix

Division of Hematology, Medical University of Graz, Graz, Austria

D. Wolff

Department of Internal Medicine III, University Hospital Regensburg, F. J. Strauss Allee 11, 93053 Regensburg, Germany 
indicated otherwise in a credit line to the material. If material is not included in the article's Creative Commons licence and your intended use is not permitted by statutory regulation or exceeds the permitted use, you will need to obtain permission directly from the copyright holder. To view a copy of this licence, visit http://creativecommons.org/licenses/by/4.0/. 